\title{
The Potential of Jenderal Soedirman's Short Film as Learning Media in National Events of the Colonial Period's Material for Fifth Graders: A Semiotics Analysis
}

\author{
Encep Supriatna $^{1 *}$, Ratu Tiara Savira ${ }^{2}$ D \\ 1,2 Universitas Pendidikan Indonesia Kampus Serang, Banten, Indonesia \\ e-mail: cepsup1976@gmail.com
}

\section{A R T I CL E I N F O}

Article history:

Received June 24, 2021

Revised June 25, 2021

Accepted July 10, 2021

Available online August 25, 2021

Kata Kunci:

Semiotika, Jenderal Soedirman,

Media Film, Nasionalisme

Keywords:

Semiotics, Jenderal Soedirman,

Film Media, Nationalism

DOI:

http://dx.doi.org/10.23887/jet.v5i 3.36022

\begin{abstract}
A B S T R A K
Kisah Jenderal Soedirman sebagai salah satu tokoh nasional dalam merebut kemerdekaan Indonesia dari tangan penjajah telah banyak divisualisasikan dalam film. Film-film yang mengandung peristiwa-peristiwa mengenai perebutan kemerdekaan tersebut tentunya perlu dipelajari, dipahami dan diingat agar tertanam nilai-nilai nasionalisme. Film ini berpotensi dijadikan media pembelajaran dalam mengemas cerita kedalam sesuatu yang menarik dan bermakna bagi siswa sekolah dasar. Tujuan penelitian ini yaitu menganalisis film pendek Jenderal Soedirman sebagai media pembelajaran pada materi IPS peristiwa kebangsaan masa penjajahan di kelas $V$ sekolah dasar. Pendekatan yang digunakan adalah pendekatan kualitatif. Metode penelitian yang digunakan adalah analisis semiotika Roland Barthes yang memfokuskan pada tanda atau simbol sebagai penanda yang dimaknai dengan makna denotasi, makna konotasi dan mitos pada sebuah film. Teknik pengumpulan data yang digunakan adalah observasi, jurnal siswa, angket, serta dokumentasi. Berdasarkan hasil penelitian dan pembahasan mengenai analisis semiotika film pendek Jenderal Soedirman sebagai media pembelajaran pada ketiga makna tersebut membuktikan bahwa peneliti dapat lebih memahami makna tersembunyi yang terkandung dalam film. Peneliti dapat lebih mengenal sosok Jenderal Soedirman, mengetahui mitos yang dipercayai oleh masyarakat pada masa perebutan kemerdekaan Indonesia serta film ini dapat digunakan sebagai media pembelajaran karena dapat meningkatkan motivasi belajar siswa dibuktikan dengan nilai yang diperoleh mencapai 3,00 dengan kategori cukup baik.
\end{abstract}

\section{A B S T R A C T}

The story of General Sudirman as one of the national figures in seizing Indonesia's independence from hard work has been visualized in the film. Of course, films related to events regarding independence need to be studied, understood and remembered so that the values of nationalism are embedded. This film is used as a learning medium in packaging stories into something interesting and meaningful for elementary school students. This study aims to analyze the short film of General Sudirman as a medium of learning in the social studies material of the colonial era in the fifth grade of elementary school. The approach used is the approach. The research method used is Roland Barthes' semiotic analysis which focuses on signs or symbols as markers interpreted with denotative meanings, connotative meanings and myths in a film. Data collection techniques used are observation, student journals, questionnaires, and documentation. Results Based on the research and discussion of the semiotic analysis of General Sudirman's short film as a medium of learning the three meanings, researchers can better understand the hidden meanings contained in the film. Get to know more about the figure of General Sudirman, know the myths believed by the public during the struggle for Indonesian independence and this film can be used as a learning medium because it can increase students' learning motivation with the value obtained reaching 3.00 with a fairly good category.

This is an open access article under the CC BY-SA license. Copyright (C) 2021 by Author. Published by Universitas Pendidikan Ganesha.

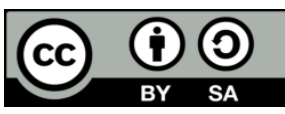

\section{INTRODUCTION}

A national hero is a person who is given a title and has an important role in the struggle and sacrifice for the independence of the Indonesian nation, the death of a national hero leaves a great work for the development and progress of this country (Defourny et al., 2019; Haas et al., 2013). The role of a national hero who has a great influence, of course, needs to be studied in order to grow a sense of nationalism within a 
person (Lyon, 2021; Nongkhai \& Phakdeephasook, 2017). Jenderal Soedirman was one of the national heroes who participated in many roles in the struggle for the independence of the Republic of Indonesia. However, the available teaching materials and teaching materials do not contain many stories about the national heroes. Social studies learning in elementary school is one of the subjects that emphasizes social values, community behavior and as a subject that facilitates students to examine events in the past, such as historical events during the struggle for independence (Te?ileanu Angela, 2014; Budiaman et al., 2021). Historical events have an important role as a sign of the integrity of the country in the future. The need for teachers to package social studies learning in elementary schools in a more interesting and fun way so that they can increase students' enthusiasm and motivation to learn (Teşileanu Angela, 2014; Wakabayashi \& Ishikawa, 2011). One of which is with films. Film is one of the works of human art that can be used as a medium of learning. Film is one type of audio-visual-based tool that can be used to achieve learning objectives and make it easier for teachers in the process of delivering subject matter (Hendrick et al., 2019; Nongkhai \& Phakdeephasook, 2017). By making the film as a medium of learning, students must be able to activate and focus their eyes and ears simultaneously in order to understand the content contained in the film (Gan \& Cui, 2020; Shao \& He, 2020).

Film is one of the communication media in the form of sound as well as a collection of moving images and as works of art and culture made based on the provisions of film techniques (Breitfuss et al., 2021; Chakraborty et al., 2019). Films can increase a person's imagination and concentration when watching them so that it is felt that films can be used as an effective learning media (Kamiyama et al., 2021; Sagdic \& Kosova, 2013).Something that is seen and heard simultaneously will form a long memory. Accordance with Roland Barthes (1956) usually in the film has a signifier or signified meaning (Bahri, 2020; Muqoddas \& Hasyim, 2016). In the film, the signifier and the signified appear, the researcher can call it the meaning of denotation if it is easy to understand, real and what it is. Meanwhile, behind the meaning of denotation there is a connotative meaning that is indirectly known from the text or images in the film or requires time to think in order to understand it. Myth is the belief of some people that is not necessarily true or can also be a reinforcement of the meaning of this connotation. A biographical film usually contains the figures' personal preferences to show the complete personality. Indeed, a person's likes or dislikes for something he will show through his behavior, words and beliefs (Haryadi, 2019; Tanjung \& Ramanda, 2019). Usually someone who tends to like something will approach themselves, respond well, harmonize with each other and even motivate each other. On the other hand, if he doesn't like it, he will stay away and give a negative response. The response shown by a person is based on the results of the given stimulus, but this is arbitrary or dynamic because the response can also be influenced by his emotional level. Those semiotic signals can be influential tools to validate the complete story of film (Hamidah \& Syadzali, 2016; Rita, 2016).

This is also in line with several studies which show that the use of film-based audio-visual learning media. The use of audio-visual media along with the implementation of the Role Playing method can improve student learning outcomes, activeness and motivation, besides that the material presented by the teacher is easier to understand, so that students were greatly helped in learning activities (Larue \& Watling, 2021; Michelsanti et al., 2019). The application of short film media is empirically proven through classroom action research carried out in several cycles can improve student learning outcomes (Fauzi et al., 2017; Pattemore \& Muñoz, 2020). This certainly gives an indication that the opportunity to use film as a means of delivering learning material is quite large. Of course, through this use of audio-visual media, it can indirectly invite students to listen to the film with full concentration during the learning process (Bromberek-Dyzman et al., 2021; Xu \& Wu, 2021). The use of film media in the learning framework, the results of the study show that there is a significant difference between the learning outcomes of the intrinsic element analysis material of literary works between those using film media and conventional learning, where the results of using film media are proven to be able to improve student learning outcomes (Hendrick et al., 2019; Setiawan \& Ari Oka, 2020). So that the use of film media can be an alternative in providing facilities for students to identify various things contained in the competencies that must be achieved. However in using film as media, teachers need to ensure the content of film addressing the target learning material. The previous studies only capture the potential and successful practice of using film in terms of audio visual media (Hanif, 2020; Setiawan \& Ari Oka, 2020).

This study tries to capture deeper the valid potential in case of subject matter of content. This study will contribute to the confidence level of success in using certain historical films in the classroom. Films that will be used as learning media must be in accordance with the subject matter to be delivered. Furthermore, historical films need to take more serious validation to provide better understanding of the past. In this case, Jenderal Soedirman's short films can be used as social studies learning media in elementary schools in the 
material of National Events of Colonials Period. However, before this film is shown to students, it is necessary for researchers to analyze the hidden meanings in the film. The researcher used semiotic analysis of Roland Barthes (1956) to find out the meaning of denotation, connotation and myth. In addition, with the results of the analysis, researchers can more easily tell the figure of Jenderal Soedirman to students so that students know the story of Jenderal Soedirman well. This is what prompted researchers to analyze Jenderal Soedirman's short film as a learning medium for social studies material on national events during the colonial period for fifth grade students at Elementary School in Ciceri district. This study aims to analyze the short film of General Sudirman as a learning medium for social studies material on national colonial events in fifth-grade elementary school.

\section{METHOD}

This study aimed to determine the potential of using the Jenderal Soedirman short film as learning media in Social Sciences material on National Events of the Colonial Period for fifth grade students in terms of content suitability and students' responses. The content suitability is drawn from the figure of Jenderal Soedirman, the meaning of denotation, the meaning of connotation and myth in the film. The student's response is to draw the acceptability of fifth grade students to the short film of Jenderal Soedirman as a medium of learning in Social Sciences. This study used a qualitative approach which focuses on human behavior and social phenomena. The data findings and the results of the discussion are presented in writing and words in a simple and straightforward manner.

The research method is semiotic analysis which focuses on the signs or symbols in the film (Sobur, 2006). This semiotic theory uses the theory of Roland Barthes (1956) which prioritizes the signifier and the signified whose understanding stage is developed into the meaning of denotation, connotation and myth (Bahri, 2020; Muqoddas \& Hasyim, 2016). The meaning of denotation is the real and obvious meaning, the meaning can be seen directly through the five senses while watching the film. While the connotative meaning is the meaning that relates between the signifier and the signified with social reality and the content of the film. So that the indirect meaning can be known by the audience or also known as hidden meaning. At the next stage of understanding the meaning of connotation related to social culture and existing community beliefs is called a myth. The object of the research was the short film of Jenderal Soedirman and fifth graders at the Ciceri State Elementary School became the subject. This research combines the triangulation result of observation, students' journal and questionnaire as data collecting techniques. Observation, as a research instrument, is used to find the analysis of the meaning of denotation, connotation and myth by watching, paying attention and cutting up scenes or scenes in the film.

The semiotic analysis procedure of Roland Barthes (1956) will be used as data technique analysis which is divided into two stages. In the first stage, to find out the meaning of denotation seen from the meaning of what it is in the film. Then, the connotative meaning emerges from the signifier and the signified is associated with social reality and content in the film. Then, the meaning of connotation is associated with the culture or beliefs of the surrounding community, so a myth is formed. The result of observation in semiotics analysis as the primary data compared to the other instrument result. Then, the students' journal is used to find out how far students know the figure of Jenderal Soedirman after watching the film. This understanding level is to measure the acceptable content of film. Then, a questionnaire was used to determine students' responses from the results of film screenings and documentation to strengthen the results of the research findings.

After the film was analyzed using semiotics elements, the researcher made this film as a medium of learning for fifth graders at the Ciceri State Elementary School as a research subject. Students make journals about their point of view on the figure of Jenderal Soedirman in the film and distribute a questionnaire containing 10 statement points regarding student responses to the influence of short films that are used as learning media. To calculate the questionnaire from the results of student responses, the researcher used a Likert scale (Arikunto, 2010). The description is divided into 5 categories: 1 (strongly disagree), 2 (disagree), 3 (undecided), 4 (agree) and 5 (strongly agree).

\section{RESULT AND DISCUSSION}

\section{Result}

In this section the authors depict some important scenes analysed containing the characteristics and personality of the main character. One of the focus scenes is in scene 8 which showed the ability of Jenderal Soedirman to disguise. 


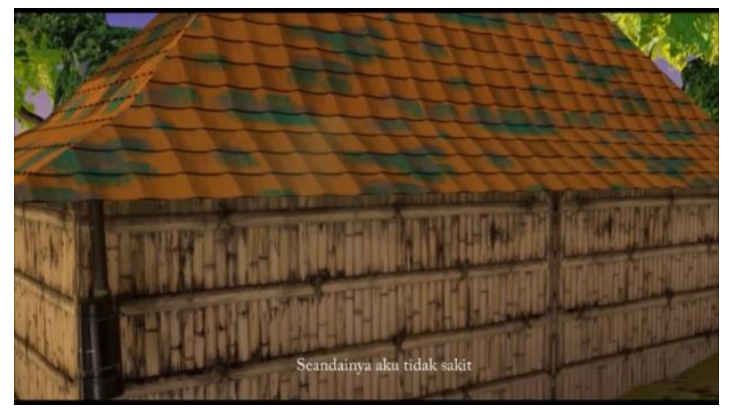

Figure 1. Scene 8

Denotation: Seen a cubicle house in the middle of the forest. Connotation: In Jenderal Soedirman's short film, this is found in scene number eight depicted with a cubicle house in the middle of the forest in which there is Jenderal Soedirman disguised as a kiyai and his soldiers disguised as santri from Jenderal Soedirman.

Myth: Some people believe that Jenderal Soedirman has a talisman because he is always able to escape from the Dutch colonial's chases. In fact, he is a warlord who has such great guerrilla tactics. For example, when someday there was a soldier who betrayed and told the whereabouts of Jenderal Soedirman in his hiding place, Jenderal Soedirman disguised himself as a kiyai and his soldiers were asked to wear sarongs and caps to disguise themselves as santri. When the traitor came with the Dutch army to his hiding place, he pointed out the location where Jenderal Soedirman was but what the Dutch soldiers saw was a man with a big cap and a hat who was leading the recitation. To feel that the traitor was deceiving him, the Dutch army shot the traitor deadly right away. This happened because the Dutch army did not recognize the face of Jenderal Soedirman due to his disguise.

Another important scene is scene 10 which showed a negotiation meeting between Dutch and Indonesian.

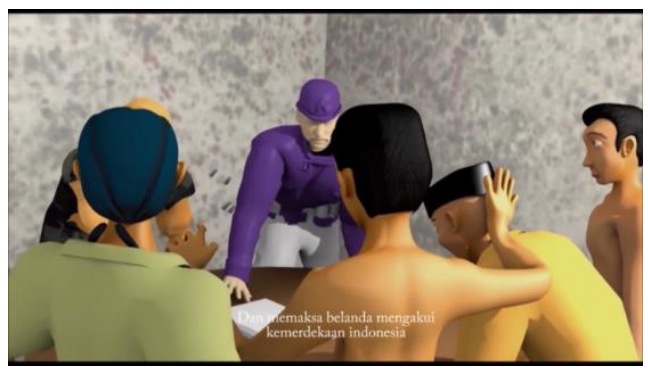

Figure 2. Scene 10

Denotation: It is interpreted as the gathering of representatives from Indonesia and the Dutch army in a round table. Connotation: In Jenderal Soedirman's short film, scene number 10 shows a gathering decorated with a round table which was attended by several representatives from Indonesia and the Dutch army. This was one of Jenderal Soedirman's attempts to make an agreement and force the Dutch to recognize Indonesia's independence.

Myth: Some people believe that Jenderal Soedirman is someone who is willing to sacrifice and willing to do anything to liberate this country. However, in reality Jenderal Soedirman was a person who did not like negotiations or agreements with any invaders. He believed that the invaders would break the promise they had made. Therefore, Jenderal Soedirman chose to carry out a guerrilla war rather than negotiations.

After the scene was analyzed, the researcher used Jenderal Soedirman's short film as a medium of learning in the Social Sciences material on the National Events of the Colonial Period for fifth grade students at the Ciceri State Elementary School. However, due to the COVID-19 pandemic outbreak around the world, Indonesia has begun to employ online learning. The learning process cannot be done in face-to-face meetings but online as an effort to prevent the spread of the coronavirus. The learning process was conducted through WhatsApp Group consisting of classroom teachers, parents and fifth grade students at the Ciceri State Elementary School. There were 25 students who attended from a total of 40 students. The learning activities used the 2013 curriculum by choosing Theme 7 Sub-theme 1, National Events during the Colonial Period, with Basic Competence of identifying important factors that caused the Indonesian nation to colonize and the Indonesian nation's efforts to defend its sovereignty.

In this online learning, the researcher acts as a teacher, at the beginning of the learning activity the teacher asks students to take their own attendance by mentioning the name and number of the absence. After that the teacher gave material about national events during the colonial period, one of which told about the guerrilla war carried out by Jenderal Soedirman and provided reading material that could be used as supporting teaching materials, then the teacher gave an animated short film of Jenderal Soedirman for students to watch and observe. 
After observing the short film, the teacher gave another learning video about the hidden meanings in a film. The teacher did questions and answers about the films that have been watched by students and invited students to ask questions about things that have not been understood. After that, the teacher gave a questionnaire via google form containing student responses about the figure of Jenderal Soedirman in the film and the responses of students or parents if the short film used as a medium in the learning process.

The following are the results of the distribution of the questionnaire distributed online through the intermediary google form. The results of the questionnaire that has been responded to by 25 respondents $(15$ female students and 10 male students) contain a wide variety of responses to the figure of Jenderal Soedirman. Then the results of the questionnaire containing 10 statement points regarding short film media if used as learning media can been on the table 2 .

Table 1. Questionnaire Results

\begin{tabular}{|c|c|c|c|}
\hline No & Statement & Results (\%) & Interpretation \\
\hline 1. & I like social studies learning using film media & $3,52 \%$ & Good \\
\hline 2. & $\begin{array}{l}\text { Sociology learning with film media makes me } \\
\text { more enthusiastic in learning }\end{array}$ & $3,36 \%$ & Good \\
\hline 3. & $\begin{array}{l}\text { Learning social studies with film media makes } \\
\text { me more motivated in learning }\end{array}$ & $3,28 \%$ & Good \\
\hline 4. & $\begin{array}{l}\text { Learning social studies with film media makes } \\
\text { me understand the subject matter better }\end{array}$ & $3,27 \%$ & Good \\
\hline 5. & $\begin{array}{l}\text { I prefer social studies learning using film media } \\
\text { than ordinary learning }\end{array}$ & $3,16 \%$ & Good \\
\hline 6. & $\begin{array}{l}\text { I am more interested in learning social studies } \\
\text { using film media than ordinary learning }\end{array}$ & $2,48 \%$ & Poor \\
\hline 7. & $\begin{array}{l}\text { I find it easier to remember material using film } \\
\text { media than ordinary learning }\end{array}$ & $2,28 \%$ & Poor \\
\hline 8. & $\begin{array}{l}\text { Learning social studies with film media makes } \\
\text { me more active in learning }\end{array}$ & $2,92 \%$ & Good \\
\hline 9. & $\begin{array}{l}\text { Learning social studies with film media makes } \\
\text { me not bored in learning }\end{array}$ & $3,32 \%$ & Good \\
\hline \multirow[t]{2}{*}{10.} & $\begin{array}{l}\text { Sociology learning using film media makes me } \\
\text { more concentrated in learning }\end{array}$ & $2,75 \%$ & Fairly Good \\
\hline & Total Average & $3,00 \%$ & Fairly Good \\
\hline
\end{tabular}

Based on the results of the total calculation of the questionnaire from 10 statement points, the average score gained is 3.00 with a fairly good category. The results of this questionnaire reflect that the use of General Sudirman's film in social science learning is able to attract students to learn more about the material, and it is proven that this short film has educational elements that can be used as role models for students.

In addition to the questionnaire, the next data is through documentation, which is packaged in the form of notes or student journals, in the student journal, they explained that the figure of Jenderal Soedirman became a National High Officer during the National Revolution. Even though his background is not from a military academy but he has an unyielding spirit so that he can join the military academy and be appointed a commander figure. He is a great man who is respected and loved by his people from all walks of life and has a brave soul. Jendereal Soedirman is responsible and continues to fight no matter what conditions he goes through to liberate the Indonesian state. The general never leaves his people even though he is sickly. He fought not only against colonialism but also his disease during his journey. Severe lung disease and tuberculosis that he suffered made him unable to walk far.

During the guerrilla, he needed a stretcher, car and even a gig to launch his guerrilla journey across forest, until one day he could no longer get out of bed because His illness was getting worse but he still carried out his responsibility as a commander in chief through communication tools to convey commands, strategies and directions to his soldiers. Because of his amazing struggle, the people dedicated their loyalty by keeping their mouths shut or silenced when the invaders often came to the village to inquire about the whereabouts of Jenderal Soedirman. Not only the people, but also soldiers admired him until when the guerrilla route leaked one of the soldiers disguised himself as 'Fake Soedirman' without any coercion to save him. Meanwhile, the soldier could be killed at any time because the invaders thought he was the real Jenderal Soedirman. The joining of Jenderal Soedirman in the military world made fellow soldiers excited. His extensive knowledge of the guerrilla and the plan to block the colonial territory went smoothly thanks to his great role (Ayuningtyas et al., 2016; Risata \& Maulana, 2016). The figure of heroism and struggle with other heroes brought this nation to victory and independence and also it can be concluded that Jenderal Soedirman suitable to be an exemplary military figure 
for all Indonesian people both from the military and the civilians (Suspurwanto, 2020; Budiman \& Sofianto, 2018).

Moreover, it is stated that Jenderal Soedirman's short film can be used as a medium for social studies learning in elementary schools because it can increase understanding, enthusiasm, motivation and it is easier to remember the material compared to ordinary learning, it was also conveyed through short film-based learning media about Jenderal Soedirman contain educational values and can be integrated into the teaching and learning process (Fitriani, 2017). Videos that present learning material well will make it easier for students to understand the material presented in the video (Gabriele et al., 2016; Nonthamand, 2020; Priantini, 2020). Learning video is one of the appropriate learning media used by teachers in teaching. In addition, well-packaged learning videos will also increase students' enthusiasm for learning (Andel et al., 2020; Teng, 2019; Tse et al., 2019). Delivering material that contain values about history has many weaknesses, such as in social studies learning for elementary school where the scope of the material still tends to be broad and general Nugroho \& Mareza (2016). This makes it clear that social studies learning in elementary schools must be accompanied by adequate learning media, sufficient criteria and in accordance with the subject matter in order to achieve interesting, fun learning, liven up the classroom atmosphere and oriented to the student-centered learning. Short films will facilitate students and provide reinforcements for the material being discussed.

\section{CONCLUSION}

The meaning of denotation in Jenderal Soedirman's short film is the real meaning, real and can be seen directly through sight as in line with the references. The connotative meaning in Jenderal Soedirman's short film is the hidden meaning of the denotative meaning. It is more specific and requires thought about the Soedirman's belief. The myth in the short film of Jenderal Soedirman is the belief of the people and culture during the colonial period. Semiotic analysis makes it easier for researchers to provide social studies learning materials and students can get to know Jenderal Soedirman well. The short film is categorized as acceptable to be used in elementary school material context.

\section{REFERENCES}

Andel, S. A., de Vreede, T., Spector, P. E., Padmanabhan, B., Singh, V. K., \& Vreede, G. J. de. (2020). Do Social Features Help in Video-Centric Online Learning Platforms? A Social Presence Perspective. Computers in Human Behavior, 113(April), 106505. https://doi.org/10.1016/j.chb.2020.106505.

Angela, Te?ileanu. (2014). Challenges to Meaningful Learning in Social Studies - The Key Competences as an Opportunity to Students' Active Participation. Procedia - Social and Behavioral Sciences, 128, 192197. https://doi.org/10.1016/j.sbspro.2014.03.142.

Arikunto, S. (2010). Prosedur Penelitian Suatu Pendekatan Praktik. Rineka Cipta.

Ayuningtyas, D. R., Suharso, R., \& Sodiq, I. (2016). Perjuangan Panglima Besar Jenderal Soedirman pada Masa Revolusi Fisik Tahun 1945-1950. Journal of Indonesian History, 5(1). https://journal.unnes.ac.id/sju/index.php/jih/article/view/19720.

Bahri. (2020). Analisis Semiotika Roland Barthes pada Masjid Keraton Buton di Kota Baubau, Sulawesi Tenggara. Jurnal Rupa, 4(2). https://doi.org/10.25124/rupa.v4i2.2314.

Breitfuss, A., Errou, K., Kurteva, A., \& Fensel, A. (2021). Representing Emotions with Knowledge Graphs for Movie Recommendations. Future Generation Computer Systems, 125. https://doi.org/10.1016/j.future.2021.06.001.

Bromberek-Dyzman, K., Jankowiak, K., \& Chełminiak, P. (2021). Modality Matters: Testing Bilingual Irony Comprehension in the Textual, Auditory, and Audio-Visual Modality. Journal of Pragmatics, 180. https://doi.org/10.1016/j.pragma.2021.05.007.

Budiaman, B., Komarudin, K., Nuruddin, N., \& Kustandi, C. (2021). Learning Design on Social Studies Through Digital Book in Senior High School. International Journal of Interactive Mobile Technologies (IJIM), 15(09), 154. https://doi.org/10.3991/ijim.v15i09.18435.

Budiman, H. G., \& Sofianto, K. (2018). Representasi Sipil-Militer dan Konstruksi Maskulinitas pada Film Jenderal Soedirman. Paradigma, Jurnal Kajian Budaya, 8(2), 155. https://doi.org/10.17510/paradigma.v8i2.220.

Chakraborty, K., Bhattacharyya, S., Bag, R., \& Hassanien, A. A. (2019). Sentiment Analysis on a Set of Movie Reviews Using Deep Learning Techniques. Social Network Analytics, 1. https://doi.org/10.1016/B9780-12-815458-8.00007-4.

Defourny, N., Perrier, L., Borras, J.-M., Coffey, M., Corral, J., \& Hoozée, S. (2019). National Costs and Resource Requirements of External Beam Radiotherapy: A Time-Driven Activity-Based Costing Model 
from the ESTRO-HERO Project. Radiotherapy and Oncology, 138. https://doi.org/10.1016/j.radonc.2019.06.015.

Fauzi, H. A., Komalasari, K., \& Malik, Y. (2017). Utilization of Audio Visual Media to Improve Student Learning Result in IPS Learning. International Journal Pedagogy of Social Studies, 2(1), 88-103. https://doi.org/10.17509/ijposs.v2i1.8666.

Gabriele, K. M., Holthaus, R. M., \& Boulet, J. R. (2016). Usefulness of Video-Assisted Peer Mentor Feedback in Undergraduate Nursing Education. Clinical Simulation in Nursing, 12(8), 337-345. https://doi.org/10.1016/j.ecns.2016.03.004.

Gan, M., \& Cui, H. (2020). Exploring User Movie Interest Space: A Deep Learning Based Dynamic Recommendation Model. Expert Systems with Applications, 173. https://doi.org/10.1016/j.eswa.2021.114695

Haas, C., Shved, N., Rühli, F. J., Papageorgopoulou, C., \& Purps, J. (2013). Y-Chromosomal Analysis Identifies the Skeletal Remains of Swiss National Hero Jörg Jenatsch (1596-1639). Forensic Science International: Genetics, 7(6). https://doi.org/10.1016/j.fsigen.2013.08.006.

Hamidah, H., \& Syadzali, A. (2016). Analisis Semiotika Roland Barthes tentang Fenomena Jilboobs. Jurnal Studia Insania, 4(2). https://doi.org/10.18592/jsi.v4i2.1124.

Hanif, M. (2020). The Development and Effectiveness of Motion Graphic Animation Videos to Improve Primary School Students' Sciences Learning Outcomes. International Journal of Instruction, 13(4), 247-266. https://doi.org/10.29333/iji.2020.13416a.

Haryadi, T. (2019). Analisis Iklan Televisi Sampoerna Hijau Versi "Es Kacang Ijo" dengan Pendekatan Semiotika Roland Barthes. Jadecs (Journal of Art, Design, Art Education, and Culture Studies), 1(1). https://doi.org/10.17977/um037v1i12016p\%25p.

Hendrick, L., Martono, M., \& Astuti, I. (2019). The Using of Film Media to Analyze Intrinsic Element in Literature in High School. International Journal of Learning and Instruction (IJLI), 1(2), 60. https://doi.org/10.26418/ijli.v1i2.37344.

Kamiyama, M., Shimizu, K., \& Akiniwa, Y. (2021). Estimation of Low-Cycle Fatigue Damage of Sputtered Cu Thin Films at the Micro Scale Using Deep Learning. Mechatronics, 78. https://doi.org/10.1016/j.mechatronics.2021.102606.

Larue, G. S., \& Watling, C. N. (2021). Acceptance of Visual and Audio Interventions for Distracted Pedestrians. Transportation Research Part F: Traffic Psychology and Behaviour, 76. https://doi.org/10.1016/j.trf.2020.12.001.

Lyon, M. A. (2021). Heroes, Villains, or Something in Between? How "Right to Work" Policies Affect Teachers, Students, and Education Policymaking. Economics of Education Review, 82. https://doi.org/10.1016/j.econedurev.2021.102105.

Michelsanti, D., Tan, Z.-H., Sigurdsson, S., \& Jensen, J. (2019). Deep-Learning-Based Audio-Visual Speech Enhancement in Presence of Lombard Effect. Speech Communication, 115. https://doi.org/10.1016/j.specom.2019.10.006.

Muqoddas, A., \& Hasyim, N. (2016). Representasi Anti Diskriminasi pada Film Kartun 3D Zootopia (Kajian Semiotika Roland Barthes). Andharupa: Jurnal Desain Komunikasi Visual \& Multimedia, 2(2). https://doi.org/10.33633/andharupa.v2i02.1217.

Nongkhai, K. N., \& Phakdeephasook, S. (2017). Hybrid Heroes: Cultural Hybridization in Thai Action Adventure Films from 1997 to 2010. Kasetsart Journal of Social Sciences, 38(3). https://doi.org/10.1016/j.kjss.2016.09.002.

Nonthamand, N. (2020). Guideline to Develop an Instructional Design Model Using Video Conference in Open Learning. International Journal of Emerging Technologies in Learning, 15(3), 140-155. https://doi.org/10.3991/ijet.v15i03.10842.

Nugroho, A., \& Mareza, L. (2016). Pemanfaatan Museum BRI dan Museum Jenderal Sudirman sebagai Sumber Belajar IPS oleh Siswa dan Guru SD di Purwokerto. Jurnal Ilmiah Kependidikan, 9(02), 1-12.

Pattemore, A., \& Muñoz, C. (2020). Learning L2 Constructions from Captioned Audio-Visual Exposure: The Effect of Learner-Related Factors. System, 93. https://doi.org/10.1016/j.system.2020.102303.

Priantini, D. A. (2020). The Development of Teaching Video Media Based on Tri Kaya Parisudha in Educational Psychology Courses. Journal of Education Technology, 4(4). https://doi.org/10.23887/jet.v4i4.29608.

Risata, M. N., \& Maulana, H. (2016). Penerapan Animasi dan Sinematografi dalam Film Animasi Stopmotion “Jenderal Soedirman.” MULTINETICS, 2(2). https://doi.org/10.32722/vol2.no2.2016.pp42-53.

Rita, V. N. (2016). Rasisme dalam Film 99 Cahaya di Langit Eropa Part 1 (Analisis Semiotika aalam Film 99 Cahaya di Langit Eropa Part 1. KOMUNITI, 7(2). https://doi.org/10.23917/komuniti.v7i2.2468.

Sagdic, Z., \& Kosova, I. (2013). Learning Architectural History by Movie Making: Ottoman Architecture. 
Procedia - Social and Behavioral Sciences, 106. https://doi.org/10.1016/j.sbspro.2013.12.197.

Setiawan, I. M. D., \& Ari Oka, I. D. G. (2020). The Use of Audio-Visual Assisted Google Classroom for Mathematics Course. Journal of Education Technology, 4(3), 244. https://doi.org/10.23887/jet.v4i3.28529.

Shao, J., \& He, C. (2020). Movie Fill in the Blank by Joint Learning from Video and Text with Adaptive Temporal Attention. Pattern Recognition Letters, 132. https://doi.org/10.1016/j.patrec.2018.06.030.

Sobur, A. (2006). Semiotika Komunikasi. PT Remaja Rosdakarya.

Suspurwanto, J. (2020). Kepemimpinan Strategis Jenderal Sudirman dalam Pengabdiannya sebagai Prajurit Tentara Nasional Indonesia. Jurnal Strategi Pertahanan Semesta, 6(1), 27-40.

Tanjung, S., \& Ramanda, I. (2019). Semiotics of Border (Analysis of Batas, A Film of Rudi Soedjarwo). Informasi, 49(1). https://doi.org/10.21831/informasi.v49i1.25396.

Teng, (Mark) Feng. (2019). The Effects of Video Caption Types and Advance Organizers on Incidental L2 Collocation Learning. Computers \& Education, 142. https://doi.org/10.1016/j.compedu.2019.103655.

Tse, W. S., Choi, L. Y. A., \& Tang, W. S. (2019). Effects of Video-Based Flipped Class Instruction on Subject Reading Motivation. British Journal of Educational Technology, 50(1), 385-398. https://doi.org/10.1111/bjet.12569.

Wakabayashi, Y., \& Ishikawa, T. (2011). Spatial Thinking in Geographic Information Science: A Review of Past Studies and Prospects for the Future. Procedia - Social and Behavioral Sciences, 21, 304-313. https://doi.org/10.1016/j.sbspro.2011.07.031.

$\mathrm{Xu}, \mathrm{X} .$, \& Wu, H. (2021). Audio-Visual Interactions Enhance Soundscape Perception in China's Protected Areas. Urban Forestry \& Urban Greening, 61. https://doi.org/10.1016/j.ufug.2021.127090. 